DOI 10.31558/2519-2949.2018.2.18

УДК 327(438)

Близняк О. А., Національний університет «Острозька академія»

\title{
СХІДНИЙ НАПРЯМ ЄВРОПЕЙСЬКОЇ ПОЛІТИКИ СУСІДСТВА: ПОЛЬСЬКІ ІНЦЦІАТИВИ
}

\begin{abstract}
У статті розглянуто внесок Польщі у формування східної політики Європейського Союзу. 3'ясовано иілі ЄС у Східній Свропі. Проаналізовано підстави значного защікавлення Польщі у розширенні східного кордону об 'єднаної Свропи. Доведено, що серед краӥн Центрально-Східної Свропи, які задекларували наміри та стали на шлях впровадження курсу на інтеграцію до європейських та євроатлантичних структур, Польща займала чітку позицію стосовно необхідності створення та реалізаиї̈ ефективної східної політики ЄС. Досліджено витоки та еволючію польської конщепиї̈ "східного виміру». Обгрунтовано, щяо в абсолютній більшості польських концепиій простежується бажання Польщі визначити своє місце і роль у системі координат національних інтересів та відносин із сусідніми державами, забезпечити власну безпеку та уникнути можливих загроз передусім з боку Росії.

Представлено головні аспекти та напрямки реалізації Європейської політики сусідства. Показовим є той факт, щуо ЄС виявляв бажсання поглибити відносини із своїми східними сусідами, але без конкретних перспектив їх інтеграиії. Водночас Польща виступала за можливість інтеграції у майбутньому країн, що стали об'єктами СПС. Визначено особливу лідерську роль Польщі у формуванні та реалізації иієї ініціативи. Охарактеризовано зусилля польської дипломатії у напрямку розширення СС на Схід. Окреслено спроби Польщі утвердити «східний вимір». Проаналізовано польську східну політику щодо Украӥни та Білорусі. Представлено головні обмеження СПС. Констатовано, що невизначеність конкретних иілей та стимулів, відсутність перспективи членства стали головними перешкодами на шляху ефективної реалізації східної політики СС щодо ї̈ адресатів - України, Молдови, Білорусі, Грузії, Вірменії та Азербайджану. Простежено внесок Польщі в імплементацію східної політики СС.
\end{abstract}

Ключові слова: Свропейський Союз, Польща, Свропейська політика сусідства, концепиія «східного виміру».

Постановка проблеми. Досвід інтеграційних процесів на теренах об'єднаної Європи, поступове розширення кола іiі членів спричинили підвищену увагу до проблеми формування Європейської політики сусідства. Польща виступила ініціатором створення і палким поборником не лише ЄПС, але й Східного партнерства. Зважаючи на це, цю державу називали адвокатом інтересів країн, охоплених ЄПС. Однак на сучасному етапі зовнішньо-політичні орієнтири Польщі змінили свій напрям та змушують переглянути висловлені раніше польські концепції східної політики. Сьогоднішня ситуація у двосторонніх відносинах Польщі та України приводить до висновку про недієвість заявлених концепцій нашого західного сусіда. Відтак, означені процеси диктують потребу глибше проаналізувати здобутки та обмеження політики «східного виміру» Польщі.

Мета статті полягає у висвітленні концепцій польської східної політики та внеску Польщі у розробку та впровадження східного виміру.

Аналіз останніх досліджень і публікацій. Значну увагу заявленій проблемі приділено у працях зарубіжних та вітчизняних дослідників. Серед польських вчених варто виділити праці Маріуша Машкевича, який розглянув головні ідейні витоки, засади та тенденції розвитку польської східної політики. Генезу східної політики Європейського Союзу досліджували Даріуш Мільчарек та Ольга Барбурська. Наукову вартість у руслі заявленої тематики має праця російської вченої Анни Чернової, яка дослідила роль Польщі у східній політиці ЄС. Інтеграційні процеси на теренах об'єднаної Європи $є$ предметом зацікавлення багатьох українських вчених. Праці Тетяни Сидорук присвячені вивченню теоретичних основ ЄПС, Східного партнерства та практики їх імплементації у країнах Східної Європи. Свій внесок у дослідження відносин $Є С$ та України зробила Олександра Шаповалова. Незважаючи на поважний історіографічний дискурс, досліджувана тема продовжує зберігати наукову актуальність та суспільну значущість.

(C) Близняк О. А., 2018 
Виклад основного матеріалу. По завершенню «холодної війни» у Європі сталася низка геополітичних трансформацій, які наклали свій відбиток на подальший хід історії усього євразійського континенту. Саме цей період характеризувався активізацією регіонального співробітництва у Європі, що було викликано передусім переосмисленням безпекового чинника та міждержавних відносин. Ці процеси стали початком нової хвилі регіоналізму, а сам цей принцип було покладено в основу створення та механізму реалізації політики ЄС. Регіоналізм можна визначити як інституціоналізовану співпрацю (через формальну регіональну організацію або без неї) між географічно близькими країнами $[11$, с. 78]. Так, принцип географічної близькості став ключовим в концепції зовнішньої політики $\mathrm{CC}$, яку було представлено Європейською Радою 26-27 червня 1992 р. у Лісабоні. Відповідно до цієї концепції, до сусідського простору ЄС належали:

а) країни Центрально-Східної Європи: Польща, Чехія, Словаччина, Словенія, Угорщина, Болгарія, Румунія, Литва, Латвія та Естонія;

б) країни західних Балкан: Хорватія, Боснія, Сербія, Чорногорія, Албанія, колишня Югославська республіка та Македонія;

в) середземноморські країни: Мальта, Кіпр, Туреччина, Марокко, Алжир, Туніс, Сгипет, Ізраїль, Йорданія, Палестина, Ліван та Сирія [12, с. 14].

Серед країн Центрально-Східної Свропи, які задекларували наміри та стали на шлях впровадження курсу на інтеграцію до європейських та євроатлантичних структур, Польща займала чітку позицію стосовно необхідності створення та реалізації ефективної східної політики ЄС. Спочатку таке бажання Польщі було продиктоване, швидше за все, географічною близькістю та тривалими історичними й економічними зв'язками, однак і безпековий чинник не втрачав своєї ваги, а іноді ставав навіть домінуючим. Польща активно почала формувати групу підтримки своїх східних сусідів серед країн, що були одночасно із нею претендентами на вступ до СС. Це Чехія, Словаччина, Румунія, Болгарія, Литва, Латвія та Естонія. 3-поміж названих держав, Польща проявляла найбільше зацікавлення своїми східними сусідами, на що впливали такі чинники:

- економічні (інтереси в сфері торгівлі, інвестицій, енергетики, ринку праці, тощо);

- політичні (східний вектор польської політики є питанням національного інтересу Польщі);

- безпекові (сусідство із пострадянським простором диктувало необхідність забезпечення безпеки та стабільності у регіоні Центрально-Східної Європи та Польщі, зокрема);

- історичні (тривалі історичні зв'язки між країнами, суспільні традиції у багатьох сферах життя);

- статусні (бажання Польщі стати експертом у східній політиці та головним адвокатом для країн, що охоплені Східним партнерством);

- етнодемографічні (спільні етнодемографічні корені);

- культурні, тощо.

Безумовно, Польща як і країни Центрально-Східної Європи (далі ЦСЄ) завжди відчувала себе частиною Європи і цю думку поділяв ЄС, натомість країни Східної Європи, особливо пострадянські, не розглядались ЄС як «регіон» взагалі, на чому слушно акцентував Роланд Россі [17, p. 9]. Дослідник Якуб Корейба пояснив зацікавленість Польщі у східному напрямку тим, що «враховуючи незацікавленість країн «старої Європи» в активізації політики СС щодо європейських країн пострадянського простору, за відсутності у них знання специфіки регіону і стратегічних концепцій його включення в європейську політику, Польща позиціонує себе як «експерт» СС з питань України і просуває через союзні інститути власне бачення відносин з цією державою» [5, с. 106-107]. По суті, Польща реалізовує власні інтереси за допомогою вироблення загальної політики ЄС щодо східних сусідів. 3 огляду на це, східний напрям зовнішньої політики Варшави безпосередньо пов'язаний із національним інтересом.

Проте, ще задовго до того як Польща здобула свою незалежність вона виявляла своє зацікавлення сусідами, що розташовані на Схід від іiі кордонів. Уперше свої погляди на відносини із східними сусідами поляки почали формувати ще до початку Першої світової війни, бо саме на цей час припадає суперництво двох концепцій: ягеллонської («міжмор'я» або прометеїзм) та п'ястівської. Ідейником першої концепції вважають польського військового і державного діяча, першого голову відродженої польської держави Юзефа Клеменса Пілсудського (1867 - 1935). Згідно 3 його теорією, Польща повинна ініціювати федерацію за участі України, Білорусі, Литви, Латвії, Естонії та Фінляндії і таким чином утворити антиросійський союз. У подальшому ідеї федерації лягли в основу концепції «міжмор'я», яка передбачала федерацію держав, які розташовані 
в трикутнику Балтійського, Чорного та Адріатичного морів. Назву «прометеїзм» ця концепція отримала в результаті того, що у 1926 р. у Парижі діяла організація «Прометей» учасником якої був Ю. Пілсудський. Свою діяльність ця організація спрямовувала на ослаблення Радянської Росії, через антирадянські національні рухи на територіях колишньої Російської імперії [13, с. 29]. У такий спосіб прихильники цієї концепції та учасники організації мали на меті убезпечити Польщу від Росії.

Ідейними опонентами «ягеллонців» були т. зв. «п’ясти». Концепція сформульована польським політичним діячем і публіцистом, засновником польського націоналізму Романом Дмовським (1864 - 1939). Суть висловленої ним інкорпораційної концепції з етнічною домінантою полягала у тому, щоб Польща здійснювала політику колонізації і асиміляції, забезпечуючи свої національні інтереси. На думку Р. Дмовського, «польська держава мала бути усюди, де мешкає щонайменше $60 \%$ поляків» та навіть сформулював умови визначення кордонів незалежної Польщі, які отримали назву «лінія Дмовського» [6, с. 79]. Він гостро критикував ідею своїх політичних опонентів за те, що вони акцентували свою увагу на потенційних загрозах із боку Росії, бо вважав, що польській державі існує загроза з боку Німеччини, яка не лише поглинула деякі польські території, але й має на меті асиміляцію населення. Крім того, Р. Дмовський мав сумніви щодо готовності східних сусідів Польщі до державності та навіть сформулював свою класифікацію націй. На його думку, існувало чотири типи націй: такі, що не прагнуть до незалежності; такі, що здатні до самоуправління, та мають націоналістичні прагнення; нації, які мають досвід власної державності та прагнуть ії відновити; та нації, які мають свою державу. До націй першого типу він відносив білорусів, до другого - українців, до третього - поляків, а до четвертого типу - німців. У тогочасному ідейному просторі домінуючою стала ягеллонська концепція, очевидно, через авторитет Ю. Пілсудського.

Основоположником сучасної концепції східної політики Польщі вважають відомого громадського діяча, еміграційного публіциста, редактора часопису «Культура» Сжи Гедройця (1906 - 2000). Він уперше висловив думку про те, що нормалізація відносин з країнами, які розташовані на Схід від Польщі - це запорука безпеки і гарантії незалежності держави. Сам $Є$. Гедройць був автором і палким прихильником федералістичної концепції, суть якої полягала унеобхідності утворення федерації з Україною, Литвою та Білоруссю. На його думку, «в майбутньому, не зважаючи на існування СССР, вздовж східного кордону Польщі повстануть національні держави і лише з ними вона підтримуватиме відносини» [6, с. 58]. Такі ідеї $€$. Гедройця піддавались критиці, їх вважали теоретичними, нездійсненними, іншими словами - міфом. Слід наголосити на тому, що в абсолютній більшості польських концепцій від Ю. Пілсудського, Р. Дмовського і до Є. Гедройця, простежується бажання Польщі визначити своє місце і роль у системі координат національних інтересів та відносини із сусідніми державами, забезпечити власну безпеку та уникнути можливих загроз передусім з боку Росії.

Відомі ще два погляди на східну політику Польщі: романтизм та реалізм. Романтизм передбачав підтримку демократизації колишніх радянських республік. Цей крок був продиктований необхідністю створити противагу бажанням Росії відновити домінування на пострадянських теренах, а також почуттям солідарності щодо цих країн. Відповідно до реалістичного підходу піддавати сумніву вплив Росії на колишні союзні держави, з метою утвердження «історичної місії Польщі на Сході», марно $[13,36]$. Тому, чимало дослідників поділяють думку про те, що у своїй більшості польська владна верхівка сповідувала ідеї романтизму.

На зламі 1980-х - 1990-х рр. відбулися трансформації у Центрально-Східній Європі, внаслідок яких Польща опинилася на роздоріжжі та змушена була торувати свій власний шлях подальшого політичного поступу. Для Польщі, яка на відміну від колишніх радянських країн, не зазнала шкоди комуністичного режиму в таких масштабах, було значно легше впоратися із новими викликами часу. У 1991 р. було припинено діяльність Організації Варшавського Договору (ОВД), після чого Польща задекларувала намір інтегруватися до європейських структур. Як результат, 15 лютого 1991 року три країни із постсоціалістичного табору: Польща, Угорщина та Чехо-Словаччина створили так звану “Вишеградську групу” (V 4). Будучи географічно у центрі Свропи, новостворена Республіка Польща обрала проєвропейський вектор свого розвитку. В подальшому поляки намагалася налагодити добрі стосунки із країнами Заходу, активізували свою діяльність на міжнародній арені, що принесло їм хороші дивіденди у короткостроковій перспективі. Успішною була і внутрішня політика Польщі. В державі було проведено президентські та парламентські вибори, схвалено Основний закон та здійснено термінові реформи у суспільній сфері. Керманичі 
країни часто вимушені були вдаватися до непопулярних рішень та реформ, поставивши перед собою мету - інтегруватися до ЄС.

Вже у 1991 р. Польща підписала Договір про дружбу з Францією, Договір про добросусідство і дружню співпрацю з ФРН, Угоду про асоціацію з ЄС, була прийнята до Ради Європи та отримала заклик на вступ до НАТО [4, с. 668]. Таким чином, Польща стала новим учасником міжнародних відносин. Вагомий вплив на становлення демократичних засад у цій країні справило міжнародне середовище. Варто віддати належне тогочасній польській еліті, яка виявилася здатною швидко реагувати на зміни у міжнародному середовищі. Польща першою серед країн, що були у фарватері впливу радянської ідеології, визнала незалежність України у грудні 1991 р., а дещо раніше, у серпні, Литви, Латвії, Естонії. Це, без перебільшення, був історичний момент для обох сторін, адже до цього все «спілкування» між ними здійснювалося виключно через Москву. Та навіть після таких рішучих кроків, доводилось діяти, озираючись на Кремль. Так, Варшава не змогла виправдати усіх сподівань Києва у той час, зокрема, Польщі не вдалося переконати решту учасників Вишеградської четвірки та привести Україну до цієї структури, також було відхилено пропозицію української сторони щодо утворення воєнно-політичного союзу [13, с. 41]. Незважаючи на ці обставини, Президент незалежної України Леонід Кравчук вважав Польщу не просто сусідньою державою, а «провідником у Європу». Наслідком таких взаємовідносин стало підписання 18 травня 1992 р. Договору про добросусідство, дружні взаємини та співпрацю між Польщею та Україною. Коли до влади в Україні прийшов Леонід Кучма у 1994 р., з боку польської владної еліти з'явилися закиди, що Україна не визначилась із своїм геополітичним вектором. Причини такої поведінки можна пояснити побоюваннями Польщі з приводу того, що проросійськи налаштований Л. Кучма не зможе балансувати між Заходом і Росією. Тим не менше, прихід до влади Александра Квасневського позитивно позначився на взаєминах обох країн, а запровадження президентами обох держав політики стратегічної співпраці, стало цьому підтвердженням.

Починаючи із 1998 р. поляки вели перемовини про вступ до ЄС. Їм вдалося досягти поставленої мети лише 1 травня 2004 р., коли Польща стала членом ЄС. Попри несприятливі зовнішньоекономічні умови вступу країни до ЄС такі, як слабка динаміка розвитку держав ЄС чи зростання світових цін, польська економіка напрочуд легко справилась 3 включенням іiі до структур ЄС i переходом до функціонування в межах внутрішнього ринку [9, с. 11]. Внаслідок цього поступово почала зміцнюватися національна валюта, зросли інвестиційна привабливість та темпи збільшення імпорту. Загалом, інтеграція до ЄС призвела до значних змін у таких важливих сферах, як освіта i наука, медицина, культура тощо. Польща зарекомендувала себе як країна, у якій впевнено i послідовно втілюються у життя реформи, зміцнюється іiі внутрішнє становище. Все це стало підставою для завоювання позиції активного члена Європейської спільноти. Польща почала брати участь у процесах прийняття рішень $Є С$, а це, поза всяким сумнівом, стало проривом.

У 1998 р. польський міністр закордонних справ Броніслав Гемерек вперше на державному рівні проголосив ідею створення «східного виміру» [12, с.119], яку презентував як розширення можливостей співпраці з майбутніми країнами-учасниками з Центрально-Східної Свропи [16, s. 34]. Пізніше, у липні 2001 р., польське Міністерство закордонних справ оприлюднило документ «Східна політика Європейського Союзу в рамках процесу розширення ЄС на Схід: польське бачення». 3 документу можна зрозуміти реальне прагнення Варшави активно просувати кордони СС на Схід. Польський президент А. Квасневський виступив з ініціативою широкої регіональної співпраці на теренах Центрально-Східної Свропи, яка у сумі включала 17 країн цього регіону і повинна була сприяти процесам трансформації, а також спільної боротьби 3 організованою злочинністю та міжнародним тероризмом [16, s. 35]. У грудні 2002 р. Польща представила пропозицію створення нової стратегії східної політики, завдяки якій покращувалася би координація проектів 3 надання допомоги для Східної Європи від ЄС залежно від ступеня зацікавленості країни у наближенні до європейських стандартів та їх можливостями конкретної взаємодії у сфері політичній, господарській, суспільній. Особливе місце відводилося Україні, яка в майбутньому, разом із іншими країнами Східної Свропи, могла би інтегруватися до ЄС. Польща вбачала необхідним запровадження та реалізацію східної політики СС для України, Молдови, Білорусі та, що важливо, $\mathrm{i}$ для Росії. Така «зрівнялівка» не влаштовувала Росію, яка аж ніяк не вбачала себе на рівних поряд iз тими країнами, які ще зовсім недавно «жили за піi правилами». Це була третя спроба Польщі утвердити «східний вимір». Таким чином Польща долучилась до дискусій про східну політику ЄС, які активізувалися у 2002 р. після заяви міністра закордонних справ Великої Британії Джека Вітакера Стро щодо ситуації в Україні, Молдові та Білорусі. Дипломат запропонував ЄС надати 
підтримку з метою поширення та розвитку демократії та ринкових відносин у цих країнах. Така ініціатива знайшла підтримку та була продовжена Данією і Великобританією, про що свідчить запропонована цими країнами концепція «Ініціатива нового сусідства» (New Neighbours Initiative). Так для України, Молдови та Білорусі було надано статус «особливих сусідів» [7, с. 52]. Ситуацію дещо змінила пропозиція Франції та Іспанії долучити до числа адресатів нової політики ЄС середземноморські країни. Таким чином, концепція ЄПС почала містити східноєвропейську та середземноморську складову.

11 березня 2003 р. представники Європейської комісії, оприлюднили повідомлення: “Ширша Європа - сусідство: новий формат відносин із східними та південними сусідами" [18, p. 26]. Після цього було запущено механізм поетапної реалізації проекту ЄПС. За сприяння Польщі, в грудні 2004 р. Рада ЄС видала декларацію, у якій вказувалося, що "метою Євросоюзу є встановлення зміцнених i привілейованих відносин 3 Україною шляхом використання у повному обсязі можливостей Європейської політики сусідства" [9, с. 35]. До 2004 р. Польщі, а також Україні разом із іншими країнами Східної Європи, відводилась роль “буферної зони” між $Є С$ та Російською Федерацією, у збереженні якої СС був особливо зацікавлений після свого розширення. На підставі детального вивчення ситуації у країнах-партнерах, ЄС оприлюднив стратегію реалізації ЄПС, виклавши іiі у документі “Свропейська політика сусідства. Стратегія" (European Neighbourhood Policy. Strategy paper) [12, с. 37]. Було передбачено такі чотири етапи реалізації ЄПС: переговори із країнами-партнерами, розробка та прийняття індивідуальних Планів дій після детального вивчення стану справ кожної країни, імплементація та моніторинг. Фактично було покладено початок ЄПС, яка остаточно виокремилась 12 травня 2004 р. [2], а документ, який визначав іiі головні засади та принципи було підписано 14 червня 2004 p.

Передувало цьому історичне за своїми масштабами розширення $Є \mathrm{C}$, в результаті якого 1 травня 2004 р. 10 країн, а саме: Литва, Латвія, Естонія, Польща, Чехія, Угорщина, Словаччина, Словенія, Кіпр та Мальта стали членами ЄС. Це розширення безпосередньо наблизило кордони ЄС до пострадянського простору та поставило перед об'єднаною Європою низку питань та завдань, на кшталт того, як будувати відносини із новими сусідами та як мінімізувати можливі ризики, пов'язані із цим сусідством. Тому, такий збіг обставин як ініціатива $Є С$ щодо своїх сусідів під назвою ЄПС та процедура розширення ЄС виглядає цілком природною і закономірною.

ЄПС поширилась на 16 країн, що межують із ЄС або ж становлять для нього значний інтерес у безпековому ключі, як, наприклад, країни Південного Кавказу. До цього списку увійшли країни Східної Європи, а саме: Україна, Молдова, Білорусь, Росія; Південного Кавказу - Грузія, Вірменія та Азербайджан; та Середземноморські країни - Сирія, Туніс, Алжир, Ізраїль, Ліван, Лівія, Сгипет, Йорданія, Марокко, Палестинська автономія [12, с. 38].

На східному напрямку СС визначив головними пріоритетами розвиток економіки, поширення демократичних цінностей, забезпечення безпеки та стабільності, а також сприяння добросусідським взаєминам. Цілі ЄС у Східній Європі, на думку фахівців, можна сформулювати у вигляді тріади: «безпека, стабілізація та європеїзація» [14, с.12].

Показовим є той факт, що ЄС виявляв бажання поглибити відносини із своїми східними сусідами, але без конкретних перспектив їх інтеграції. Водночас Польща надалі виступала за можливість інтеграції у майбутньому країн, що стали об'єктами ініціативи ЄПС. Реалізовуватися ЄПС із кожною країною-партнером повинна на підставі Угоди про партнерство і співробітництво УПС (PCA - Partnership and Co-operation Agreements), а вона, у свою чергу, через План дій ПД (АР Action Plans). План дій $\mathrm{CC}$ із країною-партнером визначається на термін від 3 до 5 років на підставі детального вивчення ситуації у різних сферах у країні та фактично є переліком завдань, необхідних для виконання.

Польща сприяла виробленню Планів дій СС-Україна, СС-Молдова, індивідуальних планів дій стосовно держав Закавказзя та ініціювала налагодження взаємин із Білоруссю. Польські дипломати домоглася позитивної відповіді від ЄС стосовно розміщення на своїй території Європейського агентства управління операційною співпрацею на зовнішніх кордонах держав-членів СС, більш відомого як Агентство управління кордонами [9, с. 37]. Керівництво польської держави неодноразово висловлювалось з приводу того, що їх країна має намір реалізувати ЄПС на східному напрямку зі своїми партнерами - Чеською Республікою, Словаччиною, Угорщиною, Естонією, Литвою, Латвією, а також зі Швецією.

Одночасно із процесами європейської інтеграції, у 2000-х рр., у Польщі відбувся прихід до влади правих правлячих сил, які апелювали до традиційних, християнських цінностей. 
Перебування при владі Леха Качинського принесло ряд змін у східний вектор польської політики. Саме у цей час Європою прокотилась хвиля так званих кольорових революцій, у ході яких Польща займала активну позицію. Загальним приводом посткомуністичних революцій стала брутальна фальсифікація політичних виборів: перших прямих виборів президента югославської федерації (24 вересня 2000 р.), президентських виборів в Україні (31 жовтня та 21 листопада 2004 р.), парламентських - у Грузії (2 листопада 2003 р.) та Киргизстані (27 лютого і 13 березня 2005 р.) [10, c. 20]. В Україні 21 листопада 2004 р., було оголошено попередні результати президентських виборів, за якими перемогу отримав проросійський кандидат - Віктор Янукович. Це викликало хвилю незадоволення серед українців, та призвело до масових акцій протесту. Команду В. Януковича звинуватили у фальсифікації виборів, згодом Верховний Суд України виніс рішення про призначення повторних виборів, на яких 26 грудня 2004 р. перемогу отримав Віктор Ющенко. Не було сумніву, що В. Януковича відверто наполегливо підтримувала Москва, а його опонента - В. Ющенка - Захід, зокрема в особі Польщі. 3 цього приводу слушним є зауваження Т. Андрущенко про те, що «внутрішньополітичний конфлікт в Україні під час Помаранчевої революції продемонстрував ключову роль України в контексті суперництва Заходу і Сходу» [1, с. 71]. Під час Помаранчевої революції польська підтримка була відчутна на президентському, урядовому, громадському та навіть медійному рівнях. Президент Польщі А. Квасневський виступив у ролі посередника між конфліктуючими сторонами, маючи особливо дружні відносини із США та спираючись на особисту підтримку президентів Франції, Німеччини та Литви. Саме А. Квасневський зумів організувати приїзд до Києва Валдаса Адамкуса та Хав'єра Солани [6, c. 266]. Така активна підтримка Польщею східного вектору не могла не викликати відповідної реакції з боку Росії, яка по завершенню Помаранчевої революції ввела ембарго на ввезення польської м'ясної продукції. Це призвело до того, що Варшава виступила проти із правом вето під час переговорів про партнерську угоду Росії з СС у 2007 р. Серед іншого, Польща запропонувала проект «Свропейської угоди про енергетичну безпеку» 3 метою уникнення в майбутньому проблем iз постачанням енергоносіїв, на кшталт російсько-української газової кризи. Усе це створювало загальний фон, на якому Варшава, зміцнивши свої позиції членством у ЄС, демонструвала спроби конкурування з Москвою за вплив у «зоні сусідства». На думку Т. Сидорук, «Польща переконана, що допомога в соціально-політичних та економічних перетвореннях у країнах Східної Свропи повинна бути однією із головних цілей $Є С$, досягнення якої не може залежати від розвитку відносин між ЄС та Росією» [12, с. 120]. 3 приходом до влади В. Ющенка між обома державами настав, за висловлюванням А. Чернової, «справжній медовий місяць» і влада Польщі ще активніше лобіювала членство України в СС. Проте, такий період у двосторонніх відносинах не був тривалим, оскільки «помаранчева коаліція» виявилась хиткою, а її розпад призвів до нової української кризи. Це співпало у часі із серйозними проблемами у міжнародному середовищі у 2008 р. як от: грузинська війна, російсько-українська газова криза, світова економічна криза тощо. У таких умовах просувати інтереси східної політики стало проблематично. Варто віддати належне наполегливості польських політиків, які сформували фронт підтримки своїх ініціатив серед країн Вишеградської групи. Вони спільно подали на розгляд Брюсселя свої пропозиції у вигляді таких важливих документів, як «Європейська політика сусідства - Східний вимір» та «Відносини ЄС-Україна: польські пропозиції». У цих документах, серед іншого, польська сторона наголошувала на необхідності пропорційного фінансування у рамках СПС для східного та південного напрямку та звернула увагу СС на проблемні аспекти політики. До таких Польща справедливо зараховувала брак механізмів для реалізації багатостороннього співробітництва, спрямування левової частки фінансових ресурсів на південний вектор, а також низьку результативність СПС через різницю в економічних, історичних, ментальних ракурсах країн, які є її об'єктами.

На особливому рахунку у східній політиці Польщі була також і Білорусь. Ця країна не тільки пов'язана спільним кордоном, історичними, культурними, економічними зв'язками з Польщею, а ще займає важливе місце у польських концепціях східної політики. Такий інтерес випливає із позицій безпеки, який для Польщі завжди був і залишається пріоритетом номер один. Особливість Білорусі, 3 погляду геополітики, полягає у тому, що вона розташована «на межі двох світів - європейського та російського» [3, с. 32]. Саме Білорусь продовжує залишатись найбільшим прихильником Росії. Таку «материнську» спорідненість з Москвою, дослідники пояснюють тим, що «на момент розпаду СРСР, не було республіки, менш готової, насамперед культурно і психологічно, до незалежності, ніж Білорусь... Це була «вітрина» радянської влади, найбільш радянська 3 усіх радянських республік» $[8$, с. 28]. 
Після розпаду СРСР між Польщею та Білоруссю не було серйозних приводів для суперечок 3 питань спільного історичного минулого (скажімо, як у випадку із Україною), однак незадоволення у білорусів все ж таки викликали місіонерська діяльність католицької церкви, претензії на Білостоцький район та діяльність Союзу поляків [13, с. 40].

У 1994 р. до влади у Білорусі прийшов Олександр Лукашенко, що позначилось на стосунках як із Польщею, так із СС, які справедливо вбачали у новообраному президентові «вірного слугу» Росії. Дипломатичні відносини Білорусі з СС розпочалися з 1995 р. підписанням 6 березня було підписано Угоду про партнерство і співробітництво між Білоруссю та ЄС, а 10 березня 1995 р. Білорусь підписала Угоду з Радою Свропи [3, с. 32]. 31994 р. О. Лукашенко обирався президентом країни у 2001, 2006 рр., а потім на референдумі було узаконено дозвіл на переобрання його на цю посаду на необмежену кількість разів, що фактично дозволило залишатися при владі безстроково та перетворитися на диктатора. Це не могло не викликати невдоволення зі сторони $Є С$, який відразу ж висловився про нелегітимність такого референдуму. У відносинах із Білоруссю з'явилося значне напруження. У 1997 р. СС відмовив у ратифікації договору про партнерство і співробітництво. Головним аргументом проти ратифікації були недотримання прав людини та порушення демократичних прав та свобод. Крім того, у лютому 1997 р. Рада міністрів $Є С$ прийняла рішення про припинення усіх видів спеціальної допомоги Білорусі за винятком гуманітарної і програм регіонального та демократичного розвитку [3, с. 33]. Згодом ця країна знову опинилась у центрі пильної уваги. Влітку 1998 р. уряд Білорусі звернувся з вимогою до закордонних представництв звільнити свої дипломатичні резиденції у м. Дрозди. Після такого кроку ряд країн: Німеччина, Франція, Велика Британія, Італія, Греція, США та Японія на знак протесту проти порушення Віденської конвенції, відкликали своїх послів із Мінська. У відповідь на такі дії міжнародної спільноти, Білорусь у грудні 1999 р. заявила про намір створити з РФ Союзну державу. У ситуації що склалася, Польща використовувала інструмент критичного діалогу: вона критикувала Мінськ за допущені помилки та одночасно підтримувала контакти 3 важливих питань. Таку обережність Варшава проявляла через побоювання, що Білорусь може цілком повернутись в «обійми» Москви. Залучення Білорусі до ініціативи ЄПС мало на меті поступову зміну риторики 3 подальшим процесом налагодження ринкових економічних відносин та демократизації останньої. Втім, білоруський вектор у польській східній політиці досі є найслабшим.

Попри всі намагання Польщі експортувати свій власний досвід до країн, на які поширилась $€ П С$, було багато проблемних аспектів цієї ініціативи. Низка дослідників поділяють думку про те, що ряд недоліків ЄПС закладено ще на етапі створення проекту. Першим таким неоднозначним фактором є географічне охоплення різних країн в межах однієї політики. ЄПС стала об'єднанням середземноморської та східної політики та країн, що лежать у вказаній площині, відповідно. Це виражається в об'єднанні відмінних за багатьма параметрами держав, а також у різниці очікувань цих країн від співпраці із ЄС. Така асиметрія можливостей і очікувань, «розмиті» стимули зі сторони ЄС, відсутність конкретних умов не сприяли зміцненню ЄПС. Як стверджує Р. Даунрейтер, політика «одного розміру для всіх» контрпродуктивна, оскільки вона принижує амбіції тих, хто щиро прагне до тісніших стосунків із $\mathrm{CC}$, а тому, щоб підтримати європейські прагнення цих країн необхідний більш диференційований підхід, оскільки зрозуміло, що Україні та Молдові дуже незручно під однією парасолею з Сирією та Єгиптом» [15, s. 185]. Суттєвим недоліком проекту можна вважати і відсутність перспективи членства для країн, оскільки запропонована ЄС «модель інтеграції без членства» не призвела до вагомих змін у країнахпартнерах. Особливе місце у співпраці ЄС зі східними сусідами займає формат відносин з Росією, яка відмовилась від участі в ЄПС через власні амбіції, оскільки «офіційна Москва хоче перших ролей у європейському концерті, а не животіння на узбіччі сучасної європейської неоімперії» [12, c. 38]. Слабким місцем ЄПС вважають недофінансування проекту. 3 цього приводу Польща висловлювала свою позицію, більше того, звертала увагу «об'єднаної Європи» на потребу пропорційного розподілу фінансової допомоги СС для південного та східного вектору ЄПС.

Висновки. Можна впевнено констатувати, що Варшава стала головним адвокатом інтересів країн, охоплених ЄПС. Такий підвищений інтерес цієї держави до країн, що стали об'єктами східної політики $\mathrm{CC}$ можна пояснити передусім спільними історичними, культурними, соціальними та економічними зв'язками. Вагомим аргументом став власний досвід Польщі у питаннях інтеграції та добре розуміння специфіки сучасної Східної Свропи, а тому цілком логічним здавалося бажання цієї країни бути своєрідним «експертом» у східній політиці ЄС. Чинник безпеки у цьому ключі відіграв вагому роль, оскільки він був присутнім у всіх без виключення концепціях польської східної 
політики впродовж всього XX і початку XXI ст. Слушною з цього приводу є думка відомого польського дипломата, соціолога та публіциста Маріуша Машкекича про те, що «польська активність на Сході $є$ наслідком раціональної політики, спрямованої на зміцнення системи безпеки у цій частині Європи ... бо для Польщі є природним чинити активний опір спробам відновлення авторитарних і тоталітарних систем у країнах постсовєтського простору. Адже рано чи пізно вони створять загрозу польському суверенітетові, а в кінцевому підсумку й цивілізаційним досягненням всієї Європи» [Цит. за: 6, с. 161-162]. Польща доклала вагомі зусилля на шляху до включення пострадянських країн-сусідів ЄС в орбіту його впливів. Її державні діячі та дипломати стали фундаторами та натхненниками ЄПС. Реалізація політики сусідства на різних етапах залежала від політичної конфігурації, зовнішніх впливів інших держав та політичної волі адресатів ЄПС. Недостатня дієвість ЄПС сприяла в майбутньому ії переформатуванню у Східне партнерство, ініціатором та найпалкішим прихильником якого вкотре виступила Польща.

\section{Бібліографічний список:}

1. Андрущенко Т. Зовнішні чинники президентської виборчої кампанії 2004 року / Тетяна Андрущенко // Політичний менеджмент. - 2005. - №3(12). - С. 71-79.

2. Гаспарян А. «Східна політика» ЄС: до і після Вільнюського саміту / А. Гаспарян. Режим доступу: http://uaforeignaffairs.com/ua/ekspertna-dumka/view/article/ckhidna-politika-jes-do-i-pislja-vilnjuskogo-samitu

3. Дорошко М.С. Держави пострадянського простору у світовій політиці / М.С. Дорошко, Н.В. Шпакова. - К.: Знання, 2010. -68 с.

4. Зашкільняк Л. Історія Польщі: від найдавніших часів до наших днів / Леонід Зашкільняк, Микола Крикун. - Львів, 2002. - 752 с.; іл.

5. Корейба Я. Проблемы региональной интеграции. Влияние Польши на политику ЕС в отношении постсоветских стран в Юго-Восточной Европе. Основы, концепции, перспективы / Якуб Корейба // Збірник IMB КНУ ім. Тараса Шевченка «Актуальні проблеми міжнародних відносин». - К., 2011. - Вип. 103. - Ч.ІІ. C. $106-121$.

6. Машкевич М. Східна польська політика у XX - на початку XXI ст.: концепції та інтерпретації / Маріуш Машкевич. - К.: Ніка-Центр, 2015. - 312 с.

7. Мільчарек Д. Східний вектор зовнішньої політики ЄС: здобутки та проблеми / Даріуш Мільчарек, Ольга Барбурська. - Львів: Растр-7, 2016. - 156 с.

8. Орлова Т.В. Пострадянські країни: основні тенденції розвитку / Т.В. Орлова. - К.: Знання, 2010. $64 \mathrm{c}$.

9. Польща в Євросоюзі: досвід першого року членства / Наук. ред. М. Карлін, перекл. $з$ польської О. Карліної. - Луцьк: ПВД Твердиня, 2005. - 208 с.

10. Романюк О. Посткомуністичні революції / Олександр Романюк // Політичний менеджмент. - 2005. № 4. - C. $16-28$.

11. Сидорук Т. В. Європейська політика сусідства у Східній Європі: концептуально-інституційні основи та реалізація: дис. ... доктора політичних наук: спец. 23.00.04. «Політичні проблеми міжнародних систем та глобального розвитку» / Сидорук Тетяна Віталіївна. - Острог, 2012. - 487 с.

12. Сидорук Т. Політика сусідства Європейського Союзу у Східній Європі: модель інтеграції без членства. Монографія / Т. В. Сидорук. - Львів: ПАІС, 2012. - 442 с.

13. Чернова А.В. Роль Польши в восточной политике ЕС: дис. ... канд. полит. наук: спец. 23.00 .04

«Политические проблемы международных отношений, глобального и регинального развития» / Чернова Анна Валерьевна. - М., 2014. - 250 c.

14. Шаповалова О. Східна Європа в Європейській системі міжнародних відносин / Олександра Шаповалова // Зовнішні справи. - 2009. - № 12. - С. 10 - 14.

15. Dannreuther R. Developing the Alternative to Enlargement: The European Neighbourhood Policy / Roland Dannreuther // European Foreign Affairs Review. - 2006. - Vol.11. - №2. - P. 183-201.

16. Milczarek D. Polska jako kreator polityki wschodniej Unii Europejskiej // Studia Europejskie. Centrum Europejskie Uniwersytetu Warszawskiego. - Warszawa, 2015. - № 4 (76). - S. 27 - 48.

17. Rossi R. The European Neighbourhood Policy in Perspective / R. Rossi // European Neighbourhood Policy: Political, Economic and Social Issues / R. Rossi, F. Attina // The Jean Monnet Centre «Euro-Med». Department of Political Studies. - Catania, 2004. - P. 8 - 15.

18. Wider Europe - Neighbourhood: New Framework for Relations with our Eastern and Southern Neighbours. COM 2003/104. - Luxembourg: EUR-OP, 2003. - 26 p.

\section{Blyzniak O.A. Eastern Dimension Policy: Polish Initiatives}

The article analyzes the contribution of Poland to the formation of the Eastern policy of the European Union. The goals of the EU in Eastern Europe are outlined. The reasons for Poland's considerable interest in expanding the Eastern border of the united Europe are explored. The article proves that among the EastCentral European countries which declared the intention and committed themselves to integration to 
European and Euro-Atlantic structures Poland firmly supported the need for creation and realization of effective Eastern policy on the part of the EU. The origins and evolution of the Polish concept of the «eastern dimension» of the EU policy are explored. The article argues that the absolute majority of Polish concepts reveal the wish of Poland to identify its place and role in the reference system of national interests and relations with neighrouring countries, ensure its safety and avoid possible threats primarily from Russia.

The main aspects and directions of implementation of the European Neighborhood Policy are presented. It is telling that the EU expressed a wish to deepen its relations with its Eastern neighbours, although without concrete prospect of their integration. Meanwhile, Poland supported a possible future integration of countries which became the objects the ENP. The particular leading role of Poland in the formation and implementation of this international initiative is also determined. Furthermore, the efforts of Polish diplomacy regarding the EU enlargement to the East are specified. The article outlines the attempts of Poland to adopt the "Eastern Dimension» and analyzes the Polish eastern policy concerning Ukraine and Belarus. It is conculded that uncertainty of goals and stimuli, lack of membership prospects have become the main obstacle to effective realization of the EU's Eastern Policy towards its addressees - Ukraine, Moldova, Belarus, Georgia, Armenia and Azerbaijan. Finally, the contribution of Poland to the implementation of the EU's Eastern policy is traced.

Key words: European Union, Poland, European Neighborhood Policy, concept of «eastern dimension». 